\title{
Entre a Religião e o Socialismo: Retrilhando Caminhos Vivenciais, Teórica e Epistemologicamente [Memorial] ${ }^{1}$
}

\author{
Between Religion and Socialism: Re-tracing Experiencial Paths, \\ Theorically and Epistemologically (Memorial)
}

\author{
Marcelo Ayres Camurça ${ }^{2 *}$ \\ “J'ai souvent pensé c'est loin la vieillesse. \\ Mais tout doucement la vieillesse vient \\ Petit à petit par délicatesse \\ Pour ne pas froisser le vieux musicien \\ Si je suis trompé par sa politesse \\ Si je crois parfois qu'elle est encore loin..."
}

(Les Cerisiers - Jean Ferrat)

\section{Introdução}

Para compor este memorial, dois vetores se destacaram enquanto dimensões existenciais ao longo de minha vida e que, por isso, também serviram de material para a reflexão intelectual, pesquisa e produção acadêmica: religião e socialismo.

Nasci no Rio de Janeiro, numa família católica, que praticava este catolicismo mediano paroquial ou acompanhava os ritos de passagem do calendário católico: Semana Santa, Páscoa, Natal, batizados, casamentos, missas de $7^{\circ}$ dia. Estudei em colégios católicos e, dessa forma, posso dizer que tive uma formação católica em termos de valores, conhecimento de sua "história sagrada" e de seus rituais.

\footnotetext{
${ }^{1}$ Memorial defendido em sessão pública visando minha promoção para Professor Titular na Universidade Federal de Juiz de Fora (UFJF) no dia 29 de abril de 2015 perante a banca composta pelos seguintes professores titulares: Otávio Velho (Professor Emérito do Museu Nacional - UFRJ), Reginaldo Prandi (USP), Carlos Alberto Steil (UFRGS) e Daniel Aarão Reis (UFF).

*Professor Titular do Departamento de Ciência da Religião da UFJF e do Programa de Pós-graduação em Ciência da Religião da UFJF. Email: mcamurca@terra.com.br
} 
Na adolescência, contudo, como parte de minha geração que se politizava no clima de combate à Ditadura Militar que imperava no país, comecei a me aproximar da esquerda organizada. Desenvolvi, então, outra formação ético-intelectual no âmbito de uma literatura marxista, seus clássicos, mas, sobretudo, seus manuais de divulgação e comentadores. Na universidade, em que ingressei em 1977, optei pelo curso de graduação de História na Universidade Federal Fluminense (UFF), paradigma de lugar de conhecimento, de resistência ao obscurantismo e da eleição da realidade e reflexão histórica como locus crucial para a compreensão da realidade social e política. Afinal, como disse Rubem César Fernandes, para a época:

\footnotetext{
'História' para nós era um conceito muito forte, que reunia e englobava o conjunto de nossas percepções sobre a existência (...) era também, para nós, a ciência das ciências, pois o conjunto dos processos objetivos ou sociais seria estruturado significativamente segundo a marcação própria do tempo (FERNANDES, 1989:37).
}

Por volta de 1978, engajei-me numa corrente política clandestina de feição marxistaleninista, o MR8, e, desta forma, no decorrer dos anos 1980 até o período da redemocratização do país, desenvolvi uma intensa atividade de militância que absorvia toda minha reflexão e consequente ação ético-política, referenciada, é claro, na segurança da "linha política" partidária, guia e bússola de toda intervenção dentro da instância coletiva do modelo de partido comunista.

Importante dizer que após a reconstrução da União Nacional dos Estudantes (UNE), em 1977, e a irrupção de um pujante movimento social e operário com greves e manifestações de massa pipocando pelo país, nosso agrupamento comunista, com grande influência no Rio de Janeiro, decidiu disseminar-se pelo país, exportando seus "quadros" por diversas regiões do mesmo. Eu, por ter raízes familiares no Ceará, fui designado para ir morar lá, e consequentemente, fiz vestibular de novo e ingressei no curso de História da Universidade Federal do Ceará para militar no movimento estudantil.

No final dos anos 1980, fatigado deste monismo existencial, de um holismo a presidir todas as minhas reflexões e pensamentos e também de uma saturação das promessas teleológicas de uma História demiúrgica apontando para a inexorável vitória da "revolução", afinal, como disse Daniel Aarão Reis Filho, "a revolução faltou ao encontro" (1989), fui gradativamente me afastando desta organização político-revolucionária.

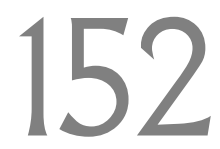




\section{a- Mestrado em Sociologia: história política e religiosidade popular}

Um dos indicadores desta minha busca por uma pluralidade intelectual, epistemológica e temática diante da visão do totalizante do agrupamento leninista ao qual pertencia, foi a decisão de realizar um Mestrado em Ciências Sociais na Universidade Federal do Ceará. Minha dissertação, intitulada " $A$ comunidade do Joaseiro na terra dos coronéis" (1987), publicada mais tarde com o título de "Marretas, molambudos e rabelistas: a revolta de 1914 no Juazeiro" (1994), foi defendida na banca presidida por Eduardo Diatahy Bezerra de Menezes, meu orientador, tendo como membros a socióloga Teresa Frota Haguette e o antropólogo e padre Charles Berlyer, ex-aluno de Bastide, ambos já falecidos. Este estudo já apresentava uma perspectiva mais nuançada de abordagem em relação ao esquematismo prevalente do modelo marxista-leninista em que me formara: etapismo histórico necessário, determinância da infraestrutura à superestrutura da sociedade, contradições principais e secundárias, burguesia nacional $\mathrm{x}$ imperialismo etc.

Ao realizar uma história regional do sertão do Cariri em conexão com a realidade urbana de Fortaleza e os conflitos oligárquicos entre facções no poder e em busca dele na República Velha, deparei-me com um mosaico de forças político-sociais, classes, frações de classe, grupos de status (romeiros do sertão, capangas e cangaceiros, latifúndio e comércio de exportação, setores populares urbanos, jangadeiros, funcionários públicos, jornalistas, burguesia liberal etc.). Esta realidade complexa me fez relativizar um esquema teórico dualista e gradualista, segundo a crítica de Chico Oliveira (1977) a uma esquerda rígida na qual tinha me formado: das contradições entre comércio $\mathrm{x}$ latifúndio, burguesia $\mathrm{x}$ 'coronéis', progressistas x reacionários. Serviram-me as leituras da historiografia mais arejada e menos esquemática de Paulo Sérgio Pinheiro (1977), Boris Fausto (1972) e do brazilianist Ralph Della Cava (1977) ao mostrar as conexões, acomodações, porosidades, meandros e sinuosidades entre grupos, partidos, classes, religiosos e positivistas, até então colocados de forma antagônica condicionada por determinismos estruturais. Da mesma forma, a abordagem mais complexa de Nicos Poulantzas em relação ao marxismo ortodoxo ao ver o Estado não como um instrumento de dominação de uma classe sobre

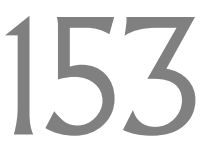


outra, mas como uma "condensação material de uma relação de forças entre classes e frações de classe" (POULANTZAS, 1980, p. 147).

Mas uma das trilhas mais significativas para minha formação desenvolvidas nesta dissertação foi a descoberta da temática da "religião popular" ou "catolicismo popular", que promoveu em mim um reencontro e uma revalorização da questão religiosa, rejeitada, dentro da já clássica visão marxista do "ópio do povo", durante meu período de militância comunista. Através de um estudo sobre o papel do Padre Cícero, do "milagre" promovido por este, da construção de uma "cidade santa" no Juazeiro com seus romeiros, beatos e beatas e as consequentes práticas e crenças de um catolicismo bastante singular, pude perceber a centralidade da religião na construção social e simbólica desta realidade. $E$ a inspiração aqui foi Antonio Gramsci, o teórico marxista que tinha preocupações com a dimensão religiosa como uma das forças constituintes do social e suas transformações, particularmente o livro de Hugues Portelli "Gramsci et la question religieuse" (1974) que resenhou e indicou na obra gramsciana estes aspectos.

O exercício pioneiro de utilização da teoria gramsciana como instrumento teórico para a compreensão do fenômeno da "religião popular" no Nordeste e particularmente para o fenômeno do "milagre" do Juazeiro, deu-se na obra de Luitgarde Oliveira Cavalcanti Barros, "A Terra da Mãe de Deus" (1988). Sou devedor a esta obra, que me redimensionou o papel da chamada "religião popular", para num segundo momento construir minha própria perspectiva.

Aplicando as formulações de Gramsci ao Nordeste brasileiro do século XIX, a autora constatou a preeminência da religião católica na formação da cultura e sociedade nordestina, assim como apropriações distintas do patrimônio religioso católico: a do clero e hierarquia eclesiástico-institucional e a dos beatos potencialmente articuladores de uma religião popular autônoma. Foi pela decodificação operada pelos beatos na teologia católica, interpretando-a como conjunto de máximas para conduta prática, que se formaram as comunidades das "religiões populares" de Canudos, Caldeirão e Juazeiro (BARROS, 1988). No entanto, já na minha pesquisa, pelo fato do líder do Juazeiro viver uma situação ambígua, como um "nativo" que era, de um lado, formado nos códigos culturais da religião sertaneja dos beatos, mas também, de outro, um sacerdote

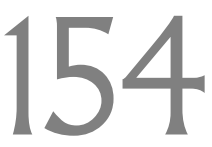


funcionário do aparelho eclesiástico e intelectual da instituição, a comunidade do Juazeiro, pelas suas mãos, faria um pacto com as oligarquias, temperando e matizando tendências mais autonomistas e radicais das demais e assim, ao contrário destas suas congêneres, sobreviveria ao aniquilamento (CAMURÇA, 1994).

Interessante notar que, ao privilegiar a referência gramsciana para a interpretação do papel da religião no contexto nordestino da minha pesquisa de dissertação - e, neste particular, Gramsci funcionando como autor de transição entre minhas convicções comunistas e minha gradativa abertura para o fenômeno religioso - ainda desconhecia outros desenvolvimentos no tratamento das "religiões populares". Estes eu viria a conhecer e desfrutar do convívio com seus autores e obras posteriormente no Instituto de Estudos da Religião (ISER).

Estou me referindo a um campo de formulações, com pluralidade de ênfases em seu interior, distinto da noção de "religião popular" que privilegiava o caráter transformador das estruturas socioeconômicas a partir de esquemas mentais, representações e práticas veiculadas por beatos e romeiros, enunciada por mim na dissertação. Essas outras formulações centravam-se prioritariamente no papel das festas dos santos, romarias, promessas, festeiros, benzedeiras e irmandades, revelando padrões de moralidade e sociabilidade regidos pela reciprocidade ritual entre devotos e santos. $E$ aqui a referência chave não era mais Gramsci, mas Émile Durkheim (1989), com seu destaque para a função do ritual e a "efervescência" por ele produzida como constitutiva do social. Eram pesquisas conduzidas por sociólogos com formação de pós-graduação na Universidade Católica de Louvain, como Pedro Ribeiro de Oliveira (1985), antropólogos como Pierre Sanchis (1983), Carlos Rodrigues Brandão (1980), com antigas ligações católicas, mas que traziam inovações teóricas provenientes da Europa de Bastide e Bourdieu, e historiadores ligados à Comissão de Estudos de História da Igreja da América Latina (CEHILA), como Eduardo Hoonaert (1976), Oscar Beozzo (1977) e Riolando Azzi (1977), todos reunidos neste grande fórum de debates e pesquisas que foi o ISER nos anos 1970 e 1980.

Na época de minha mudança de volta ao Rio de Janeiro em 1988, fui encarregado pela organização do "I Congresso Internacional sobre o Padre Cícero e os Romeiros de

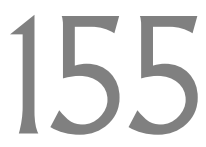


Juazeiro do Norte", patrocinado pela Universidade Regional do Cariri (URCA), de estabelecer contato com vários destes pesquisadores a fim de convidá-los para o evento. Desta forma, comecei a travar contato com muitos daqueles que viriam a se tornar mais tarde diletos colegas e amigos.

Então, no meu retorno do Ceará ao Rio de Janeiro, já desligado do MR8, pude dar seguimento a dois projetos que, cada vez mais, iam se articulando e se complementando diante de mim: compreender teoricamente a religião como algo relevante em nossa realidade e compreender o socialismo/comunismo por seus aspectos "para religiosos", simbólicos, rituais. Por estas motivações intelectuais/vitais fui levado a duas "casas" que me acolheram e a estes meus projetos: o Programa de Pós-Graduação em Antropologia Social (PPGAS) do Museu Nacional/UFRJ e o Instituto de Estudos da Religião (ISER). E, dentro de cada um destes dois ambientes, em meio às muitas referências, duas figuras se destacaram como preceptores na arte, no estilo e na ética de buscar o conhecimento e suas mediações no trato com os outros e os próximos: Rubem César Fernandes e Otávio Velho.

Alguém já disse que toda dissertação ou tese acadêmica tem como pano fundo uma questão existencial ou mesmo psicanalítica. Ou seja, trata-se de um acerto de contas - no plano teórico-epistemológico - com algo que marca indelevelmente do ponto de vista subjetivo. No caso da minha dissertação de mestrado, foi um passar a limpo uma questão atávica, familiar, pois meus antepassados - meu bisavô "coronel" sertanejo vivenciaram o evento da conflagração interoligárquica estudada. No que diz respeito à tese de doutorado, esta foi um ajuste de contas com meu passado comunista, uma catarse desta minha experiência "terrible et fascinans" - para o bem e para o mal - que foi a militância, para usar o termo de Rudolf Otto para se referir ao sagrado.

\section{b- Doutorado em Antropologia: enfoque do comunismo pelo ritual e simbólico}

Iniciei meu doutorado no PPGAS do Museu Nacional no Rio de Janeiro, em 1989, sob orientação de Otávio Velho, movido pela inquietação de "desnaturalizar", "estranhar", "relativizar" os postulados estabelecidos e sedimentados pela esquerda sobre o domínio do

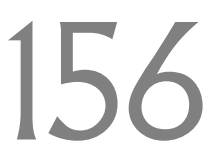


socialismo/comunismo. A antropologia me parecia ser a disciplina mais adequada para realizar este empreendimento. Mas devo dizer que foi um aprendizado difícil, que se alavancou quase do zero em torno da ciência da alteridade e da descrição etnográfica. Tive que enfrentar muitos desafios nesta pesquisa: retornar ao que fora outrora meu ambiente natural, a organização comunista a que pertencera, o MR8, agora como pesquisador. Mas também cheio de lembranças que afloravam em cada entrevista e em cada passo no "trabalho de campo", enfim, jogando o jogo do "informante de mim mesmo", nas palavras do colega Luiz Eduardo Soares à época da pesquisa. Por outro lado, tinha que controlar o meu bias de ex-militante com opiniões e juízos já definidos acerca do tema e objeto. Estas reflexões sobre as condições de produção da minha pesquisa estão contidas na tese de doutorado que se intitulou "Os 'Melhores Filhos do Povo'. Um estudo do ritual e do simbólico numa Organização Comunista: O caso do MR8". Agora, com 20 anos de espaço-tempo de sua defesa, este trabalho está no prelo em forma de livro com o título de "Os 'Melhores Filhos do Povo'. Um estudo do ritual e do simbólico no Movimento Revolucionário Oito de Outubro (MR8)", para ser publicado no primeiro semestre deste ano pela Editora Appris.

Ao concluir e defender a tese de doutorado - numa banca composta pelos professores Moacir Palmeira e José Sérgio Leite Lopes, pelo PPGAS, e Francisco Weffort (USP) e Regina Novaes (IFCS-UFR)] e presidida por Otávio Velho - julgo ter conseguido um resultado satisfatório, em que, através do "estudo de caso" do MR8, logrei lançar uma perspectiva de abordagem dos movimentos e organizações comunistas sob o viés do imaginário, do simbólico e do ritual. Penso que, se houve relevância neste trabalho, esta deveu-se ao fato de buscar cobrir uma lacuna deixada pelas teorias privilegiadamente sociopolíticas no tratamento da experiência comunista. Meu labor nesta tese foi o de estender o método antropológico utilizado em sociedades e grupos rurais e urbanos frequentemente descritos etnograficamente para movimentos e partidos políticos de esquerda, até então apenas estudados pela Ciência Política, História e Sociologia. No prefácio do livro a ser publicado como versão revisada e condensada da tese, menciono o fato de uma iniciativa semelhante à minha, mas com um fôlego incomparavelmente maior, estar, quase que na mesma época, sendo desenvolvida e liderada enquanto projeto de

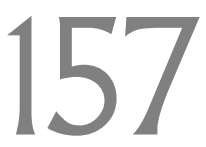


pesquisa por Moacir Palmeira, no grupo de pesquisa que foi então chamado de "Antropologia da Política".

Pretendi, nessa tese, "desnaturalizar" as regras, códigos, "linhas políticas", táticas e estratégias do esquema dado e objetivo da linguagem política da esquerda, revelando-os enquanto ritos: de iniciação, de passagem, enquanto marcas identitárias e diacríticas (totens] em relação a outros grupos. Busquei também demonstrar que as facetas das representações, narrativas, símbolos e rituais dentro da atividade política não são meros ornamentos para o seu desenvolvimento, mas partes constitutivas de sua própria estrutura. Tudo isso ensejou que eu propusesse na tese a ideia de uma "cultura comunista", gestada em mais de setenta anos de experiência exitosa de funcionamento de instituições e sociedades dentro do "modelo soviético" (da III Internacional) no mundo (Ocidente, Ásia e África).

Ressaltando o caráter memorialístico deste texto, não posso me furtar de mencionar, no período de doutorado 1989-1994, o aprendizado e a convivência com formadores na prática da antropologia no Brasil, a começar pelo meu orientador Otávio Velho, com seu pensamento sempre au-delà das formulações consolidadas e cartesianamente estabelecidas, naquilo que, segundo uma expressão muito utilizada por ele, traduzia-se sempre numa outra "volta do parafuso" possível, ou na possibilidade de "relativizar o relativismo". Ele também, a sua maneira, enredado na trama do comunismo e da religião, mas compreendendo estas dimensões pelos seus aspectos de fundamento e ornamento, tomados como iguais em importância e não antinômicos, mas porosos e complementares, no que muito à sua maneira chamou de "realismo de narrativa" [VELHO, 1992, p. 66). Em Otávio, sempre, o pensamento é que inquieta, e não o que apazigua! Em seguida, os professores nos quais fui "beber" literatura e teoria para minha "antropologia política da esquerda": Moacir Palmeira e José Sérgio Leite Lopes. Também os laços de amizade entretecidos na época com os colegas: Leila Amaral, Carlos Steil, Emerson Giumbelli, Lúcia Arrais, Wilson Azevedo, Rodrigo Grunewald, Renata Menezes; assim como com aqueles que já não estão mais entre nós, como Luis Gonzaga Piratininga e Clara Mafra. Muitos desses, mais tarde, destacaram-se na docência, na pesquisa e nas atividades institucionais da antropologia no Brasil.

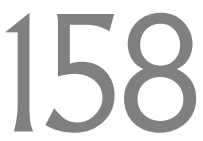


Essa pesquisa de doutorado, além do livro, versão mais compacta da tese que será publicada em breve como já mencionei, rendeu outras publicações durante e depois da publicização e defesa do trabalho. Posso citar como importantes o artigo "A concepção da História na Cultura Comunista", publicado na Série Estudos/IUPERJ (1992); o capítulo "Ética sacrifical e martirológio entre cristãos e comunistas", no livro "Exemplaridade, ética e santidade", da Loyola, (1997), e o artigo "Imaginário, símbolos e rituais nos movimentos e organizações comunistas: por uma antropologia interpretativa da esquerda", publicado em "Religião e Sociedade" (1998). Também através desta perspectiva de uma "antropologia política da esquerda", foi-me possível, tempos mais tarde, participar de homenagens a duas referências das Ciências Sociais brasileiras que influenciaram diretamente minha trajetória neste período: Otávio Velho e Luiz Werneck Vianna, ressaltando, nesses textos em homenagem a eles, imagens, ethos, narrativas e símbolos vinculados ao domínio da esquerda comunista, com que ambos estiveram envolvidos num significativo período de suas vidas. Foram os ensaios "Comunismo e Religião nas 'voltas do parafuso': o papel da narrativa e do simbólico na transfiguração do cotidiano e na criação de sentido de comunidade" (2006, p. 68-80), para Otávio, e "Werneck Vianna e suas inquietações: imagens e ethos da militância comunista", para Werneck (2012, p. 409-422).

\section{b-1- O ISER, pesquisa e intervenção sobre socialismo, religião e sociedade civil}

Minha participação no segundo nicho formador do meu aprendizado em pesquisa e intervenção social, o ISER, deu-se concomitante ao período em que realizei meu doutorado no PPGAS do Museu Nacional. Como fui estagiário e bolsista de pesquisa de Rubem Cesar Fernandes - que era docente no Museu (dividindo a área de interesse em antropologia da religião com Otávio Velho) e também o coordenador geral do ISER - fui convidado a trabalhar em projetos nesta ONG. Aliás, havia à época um fluxo de colaboração entre PPGAS e ISER pela iniciativa de Rubem Cesar, por meio do qual alunos do Programa atuavam em projetos da ONG. No meu caso e de outros colegas, tal participação se dava com a aquiescência um pouco preocupada de meu orientador, com o justo temor de que isto pudesse desviar o foco na pesquisa de doutorado. No entanto,

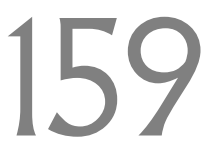


Otávio também colaborava ativamente no ISER, ocupando inclusive cargos em conselhos e diretorias da instituição.

Tive como primeira atividade no ISER um trabalho que estabelecia claras conexões com o meu tema de pesquisa de doutorado. Integrei um projeto de um jornal mensal que se chamava "Vermelho e Branco" que abordava, segundo o subtítulo de sua capa, as "transformações no socialismo". Através de seu idealizador, esta publicação expressava, ao lado das "transformações no socialismo", uma revalorização do papel da religião neste novo cenário. E isto se evidenciava na conjuntura do final dos anos 1980 e início dos 1990, da perestroika e glasnost de Gorbatchev, do "Solidarinorsk" na Polônia e do papel que jogava o Papa João Paulo II na conjuntura mundial. Nesse jornal, Rubem Cesar reuniu antigos companheiros de juventude, como Pedro Celso Uchoa Cavalcanti e o chefe de redação do periódico, o jornalista Newton Carlos. Mas também participaram do jornal o ex-frade dominicano Ivo Lesbaupin, ligado à Teologia da Libertação, membro do ISER/ Assessoria, e o historiador Daniel Aarão Reis, na época, por ser membro e liderança do PT, muito envolvido em refletir sobre a questão do socialismo e democracia neste partido que despontava.

Relendo hoje as páginas amarelecidas da minha coleção do periódico, surpreendome ao constatar que escrevi matérias na maioria das edições que cobriram os anos 19901993. Redigi artigos sobre as renovações do socialismo na URSS, sobre a chamada "revolução de veludo", ou seja, o desmembramento dos países comunistas do leste europeu da influência soviética, sua autonomização e reconfiguração democrática e capitalista, sobre a "queda do muro" e o fim do "socialismo real". Também sobre as repercussões disso no Partido Comunista Brasileiro, e, por fim, sobre experiências alternativas de entabular articulações da sociedade civil na América Latina. Estas últimas produções resultaram de uma viagem de estudos que realizei em 1993 pelo Chile, Peru, Costa Rica, Nicarágua e México sob o patrocínio de uma entidade transnacional, "Civicus - Aliança Mundial para participação de cidadãos”, visando à elaboração de um relatório, por Rubem Cesar, sobre o estado da arte do chamado "terceiro setor" na América Latina (1994).

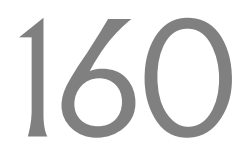


Parece-me que, naquele momento, a ideia que começou a germinar na mente de Rubem Cesar era a de potencializar experimentos de acordos e projetos de construção de uma sociedade civil enquanto inovação na cultura política da época, particularmente no Rio de Janeiro? ${ }^{3}$ Na revista "Comunicações do ISER", comemorativa dos 20 anos da ONG no ano de 1991, que abria os anos 1990, ele escreve um artigo intitulado "Votos para a nova década", no qual propugna novas "pautas e problemas", novas "articulações" e o "encontro de gente que nunca se viu" (1991:05-11). Dentro desta perspectiva, além das articulações internacionais que ele, Rubem, realizava, dentro da concepção do "terceiro setor", uma nova aliança que buscava reunir atores sociais para além do Estado e do Mercado, ou seja, o mundo da filantropia, das associações civis e das religiões; iniciativas locais eram entabuladas pelo ISER junto com seus pares buscando concretizar estas novas configurações de ação social. Exemplo disto foi o Projeto "Se essa rua fosse minha", que reuniu quatro das principais ONGs do Rio, a saber, IBASE, ISER, FASE e IDAC, para enfrentar a questão dos "meninos de rua" logo depois do episódio da "chacina da Candelária". Nesse caso, o "encontro de gente que nunca se viu" enquanto experiência de sociedade civil para o enfrentamento do problema social da infância "em situação de risco" aproximou cantores e compositores famosos, a mídia, o meio empresarial, o mundo dos esportes e do futebol, das religiões de caridade e das comunidades dos bairros de periferia. Fui designado pelo pool das ONGs promotoras da articulação para fazer o registro e a pesquisa que saiu publicada com o título "Se essa rua fosse minha... registro de uma experiência em curso" pelo Núcleo de Pesquisa do ISER (1992). Ainda como desdobramento da tarefa de registrar estas novas iniciativas em prol da defesa da infância e adolescência em risco, numa perspectiva de articulação da sociedade civil, desenvolvi pesquisas sobre o Conselho de Defesa da Criança e do Adolescente do Rio de Janeiro (1994) e sobre os Conselhos Tutelares (1999), entidades em que convergiam representantes do Estado e das ONGs numa relação de tensão e complementação de expertises e interesses.

\footnotetext{
${ }^{3}$ Para uma melhor compreensão das formulações e iniciativas de Rubem César Fernandes, ver a entrevista biográfica que ele prestou a Lúcia Lippi de Oliveira e Dulce Pandolfi, publicada sob o título de "Fora de Ordem: viagens de Rubem César" (2014).
} 
Devido à consideração de que a religião produzia atores e agentes sociais cruciais para qualquer iniciativa de aglutinação da sociedade civil no país, o ISER cumpriu o papel de estimular a criação do Movimento Inter-Religioso para se posicionar diante das candentes questões daquela época. Ainda aqui funcionou a sensibilidade de Rubem Cesar para reunir tantas e diferentes religiões e religiosidades: de feição oriental, budistas, hinduístas, xintoístas, as de cunho afro-brasileiras, Umbanda e Candomblé, as cristãs nos seus diferentes matizes, o espiritismo, grupos esotéricos etc. Esta foi uma das minhas últimas atividades no ISER, auxiliando Rubem Cesar na coordenação deste movimento. Foram realizadas Celebrações Inter-Religiosas de grande impacto e repercussão pelo seu potencial simbólico frente às urgências do nosso tempo: a celebração na ECO 92 pela preservação do meio ambiente; a que conclamou a ética na política quando do impeachment do presidente Fernando Collor; aquela que celebrou a "Campanha contra a Fome" liderada por Betinho e a que celebrou a Paz diante da violência generalizada no Rio de Janeiro, instituindo formas novas de mobilização social como aquele "um minuto de silêncio" que atravessou a cidade e o "abraço" na Candelária. Todos estes episódios aqui relatados serviram posteriormente para a constituição do movimento e da ONG Viva Rio, mas, naquele período, eu já não me encontrava mais neste projeto.

Por fim gostaria de registrar que alguns anos depois, já na condição de docente da Universidade Federal de Juiz de Fora, fui convidado a compor a diretoria do ISER para o biênio 2000-2001 na condição de tesoureiro daquela gestão encabeçada pela socióloga Nair Mulls. Exerci a função com muita honra, no período que marcou minha despedida das relações institucionais com aquela "casa" que me legou um exercício criativo de participação em formas democráticas até então inéditas de articulações da sociedade civil com os poderes públicos, assim como me permitiu uma convivência intensa com o meio religioso situado no Rio de Janeiro, o que me valeu como aprendizado prolongado de "trabalho de campo" que iria carregar para um exercício futuro de antropólogo e cientista (social) da religião.

\section{c- O Programa de Pós-Graduação em Ciência da Religião de Universidade Federal de Juiz de Fora}

162 
Ao finalizar meu doutorado no PPGAS do Museu Nacional em fins de 1994, inquietou-me a questão: seguir uma carreira de institution builder em meio à ONG, da mesma forma daquele "pai espiritual" que foi Rubem César Fernandes para mim? Naquele momento, guiado por suas mãos, dirigia a ONG criada durante a campanha "Contra a Fome" de Betinho, que era o "Fundo Inter-Religioso contra Fome". Esta instituição fazia campanha de arrecadação de fundos na sociedade e repassava para entidades que trabalhavam no meio social em projetos para minorar a desigualdade. $\bigcirc$ interessante é que o Conselho Dirigente desta $\mathrm{ONG}$, com o qual eu lidava na condição de Secretário Executivo da instituição, era composto por líderes religiosos do Rio de Janeiro, a saber: o sociólogo católico Luiz Alberto Gomez de Souza, o Reverendo Caio Fábio D’Araújo, o dirigente espírita Edvaldo Roberto de Oliveira, o sacerdote Hare Krishna Lokasaksi Das e a ialorixá Mãe Beata de lemanjá.

A oportunidade para ingressar definitivamente na vida acadêmica surgiu por sugestão do então meu colega de doutorado, Carlos Steil. Ele também trabalhava no ISER, precisamente na equipe do ISER/Assessoria, grupo que prestava assessoria - em planejamento, formulações sociológicas, análises e pesquisas - a diversas igrejas cristãs no meio católico e protestante. Compunham também a equipe, entre outros, o sociólogo Pedro Ribeiro de Oliveira e o teólogo Faustino Teixeira, ambos fundadores e membros do Mestrado em Ciência da Religião da Universidade Federal de Juiz de Fora (UFJF). Pelo contato com estes seus colegas - que depois se tornariam meus também -, Carlos avisoume da seleção que ocorreria neste departamento da UFJF para as cadeiras de sociologia e antropologia da religião. A ideia dos organizadores do concurso, penso, era de ampliar a participação das Ciências Sociais no curso de Mestrado e Especialização em Ciência da Religião.

Dentro dessa perspectiva, prestei concurso e fui aprovado em fevereiro de 1995 para o Departamento de Ciência da Religião da UFJF. A partir daí, minha biografia acadêmica mistura-se com a história do Departamento e da Pós-Graduação em Ciência da Religião, esta criada em 1993 enquanto um Mestrado, apenas dois anos antes do meu ingresso. Depois do seu fundador e primeiro coordenador por vários anos, Faustino

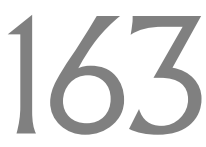


Teixeira e do colega Paulo Afonso da área de Filosofia da Religião, sou o terceiro docente mais antigo no PPCIR e no DECRE. Completo, significativamente, 20 anos "de casa" nesta mesma época em que presto este concurso para professor titular. Tenho, ao longo destes anos, acompanhado e tomado parte nas decisões e mudanças cruciais deste curso: a constituição do Programa de Pós-Graduação com a criação do seu doutorado em 1999, a subida da nota avaliativa da CAPES e sua estabilização no conceito "5" em 2001, os desmembramentos de suas áreas de concentração para o formato que possui até hoje (com modificações internas) e a criação do curso de Graduação, em 2012, do qual faço parte da composição de seu Núcleo Docente Estruturante (NDE). Ocupei a Chefia do Departamento de Ciência da Religião em 2002-2003, sendo reconduzido, em 2004-2005, e acabo de ter recentemente o privilégio de exercer o cargo de Vice-Coordenador do Programa no período de 2014-2015. Estas experiências administrativas e institucionais de operacionalizar a vida útil do Departamento e do Programa, junto às instâncias do Instituto, da Universidade, da CAPES etc., com participação em conselhos, comissões, câmaras e outros órgãos, fizeram-me compreender melhor os mecanismos pelos quais o ensino e a pesquisa podem ser viabilizados.

Assisti ao ingresso da totalidade dos 16 colegas que compõem o atual quadro do Departamento, do PPG, da Especialização e da nova Graduação à̀ exceção de Faustino e Paulo). Participei de algumas (três) bancas de seleção destes colegas para o Departamento (Fátima Tavares, Volney Berkenbrock e Francisco Luiz Pereira da Silva); assisti também à saída de colegas transferidos para outros IFES do país (Fátima Tavares e Francisco Luiz Pereira da Silva); à aposentadoria de outros (Pedro Ribeiro de Oliveira, Zwinglio Dias, Wilmar Barbosa) e à perda tão sentida de Vitória Peres por falecimento em pleno vigor de seu engajamento e maturidade intelectual.

Iniciei minhas atividades no Mestrado em Ciência da Religião [depois Programa de Pós-Graduação em Ciência da Religião - PPCIR] na UFJF já no início do ano letivo de 1995, com a incumbência de criar e ministrar a disciplina "Antropologia da Religião", e, logo em seguida, em 1997, devido à precoce aposentadoria de Pedro Ribeiro de Oliveira, passei também a me responsabilizar pela disciplina "Sociologia da Religião" e, depois, por "Campo Religioso Brasileiro", rubricadas como "gerais", às quais sucediam as chamadas

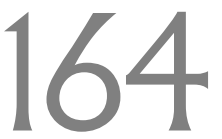


"específicas", todas formando um conjunto de disciplinas do que seria a futura área de concentração "Religião, Cultura e Sociedade". Um relato mais pormenorizado da dinâmica acadêmica desta área de concentração no PPCIR e do seu Núcleo de Pesquisa se encontra num artigo de minha autoria intitulado "Um balanço do Núcleo de Estudos do PPG em Ciência da Religião da UFJF: a religião entre as Ciências Sociais e Ciências da Religião", publicado em "Debates do NER" (2007), em volume dedicado ao estado da arte dos Núcleos de Pesquisa em Religião nos PPGS do Brasil e Holanda, com versões em português e inglês (2007). Importante frisar também que, desde 2004, sou coordenador deste Núcleo de Pesquisa intitulado "Religião, Cultura e Sociedade" segundo cadastro no Diretório de Grupos de Pesquisa do CNPQ.

Realizando um inventário sumário das disciplinas ministradas no PPCIR (Mestrado e Doutorado), na Especialização em Ciência da Religião e, mais recentemente, na Graduação em Ciência da Religião, chego ao seguinte cômputo: "Antropologia da Religião" (Mestrado e Especialização), nove vezes (1995/2; 1996/1; 1998/1; 2000/1; 2002/1; 2003/2; 2004/1; 2011/1; 2014/1); "Fundamentos Teóricos da Antropologia da Religião" (Mestrado), cinco vezes (1995/1; 1998/2; 2001/1; 2005/1; 2007/1); "Tópicos em Antropologia da Religião" (Mestrado), uma vez (2010/1); "Sociologia da Religião", três vezes (Mestrado e Especialização) (1997/1; 1999/2; 2013/2); "Teorias Sociológicas da Religião (Mestrado), duas vezes (1999/1; 2007/2); "Campo Religioso Brasileiro" (Mestrado e Especialização), cinco vezes (1999/1; 2000/2; 2001/2; 2008/2; 2011/2) "Religiões no Brasil" (Doutorado), sete vezes (2001/1; 2002/2; 2003/2; 2004/1; 2006/2; 2010/2; 2014/1); "Religiões no Brasil" (Graduação), duas vezes (2012/2; 2014/2) “Estudos Comparados da Religião” (Mestrado), uma vez (1995/1); Pluralismo Religioso na Modernidade (Mestrado), uma vez (200/2); "Espiritismo Kardecista" (Graduação), duas vezes (2013/2; 2014/1); "Introdução à Ciência da Religião" (Graduação), duas vezes (2013/1;2013/2); “Tópicos Especiais em Ciência da Religião” (Mestrado), uma vez (2011/1); “Religião e Espaço Público (Mestrado), uma vez (2012/1); "Tópicos Especiais em Religião e Espaço Público" (Mestrado), uma vez (2012/2) e “Religião, Política e Espaço público" (Graduação), uma vez (2013/2).

Passo, em seguida, a uma análise sobre as consequências desta atividade de docência para minhas formulações teóricas em pesquisas, trabalhos apresentados e publicações.

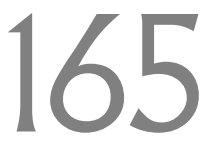




\section{c-1- Reflexões sobre as disciplinas de Antropologia da Religião e Sociologia da Religião}

O exercício de lecionar a disciplina "Antropologia da Religião", assim como suas correlatas, por diversas e repetidas vezes no PPCIR, além de ter elaborado sua ementa e sucessivos programas, fez-me entabular uma reflexão sobre o estatuto de tal disciplina dentro do campo de conhecimento da Antropologia. Estas reflexões em forma de ensaios intitulados "Em que medida pode-se falar em uma 'Antropologia da Religião' dentro do campo antropológico?" e "Em busca de 'fundamentos' para uma Antropologia da Religião: afinidades e antinomias entre antropologia e religião" foram reunidas (entre outras) no livro de minha autoria "Ciências Sociais e Ciências da Religião: interlocuções e polêmicas'(2008).

Apesar da "antropologia da religião" ter logrado obter na Antropologia realizada no Brasil um reconhecimento formal enquanto área de "especialização" antropológica, em geral, a forma canônica dispensada pela Antropologia ao tema religião parece, do ponto de vista teórico-epistemológico, desconhecer na dimensão religiosa uma realidade própria. Neste caso, a "religião" funciona menos como um lugar dado sobre o qual a teoria antropológica estabelece um conhecimento e mais como um "campo" construído artificialmente para abrigar diversos autores e teorias que distribuiriam seus interesses em sistemas simbólicos, como o mito, o rito e a magia, através dos quais o enigmático da alteridade passou a ganhar inteligibilidade. Desta forma, minha reflexão procurou situar esta "especialização" da antropologia chamada "antropologia da religião" dentro de uma "história da antropologia", verificando como autores clássicos como Malinowski, Marcel Mauss, Lévi-Strauss, Edmund Leach, Evans-Pritchard e Clifford Geertz lidaram com a questão. Neste particular, a "especialização" aparece relacionada prioritariamente a uma antropologia simbólica em torno de conceitos como kula, mana, bruxaria, tabu, eficácia simbólica do que vendo a religião como dimensão substantiva. Apesar destes autores clássicos da antropologia mencionarem na sua obra o termo "religião", nada nos autoriza a dizer que eles fizeram estritamente uma "antropologia da religião", ou nomeá-los de "antropólogos da religião". Isto, ao contrário do que se passou na Sociologia, que tornou

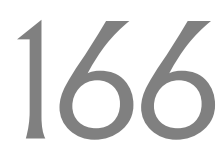


canônica uma "Sociologia da Religião" nos "pais fundadores" da disciplina como Weber, Durkheim, ou em contemporâneos como Bourdieu e Berger, devido ao formato institucional, de instância de poder, que a religião tomou nas sociedades ocidentais modernas contempladas pela disciplina. Trouxe também Otávio Velho, como alternativa para a formulação de uma antropologia da religião, com o seu argumento de "relativizar o relativismo" de uma Antropologia main-stream que, no seu afã de desconstruir ética, valores e as "grandes narrativas" (dentre elas, a religião), esqueceu-se de que a Antropologia se constituiu enquanto uma disciplina na interpretação de momentos suis generis do social das "experiências não-conceptuais", do extra-cotidiano: "os ritos de passagem", a communitas, a "efervescência" (VELHO, 1995). Estes meus ensaios desenvolvem uma argumentação, penso, mais sutil e pormenorizada, impossível de ser resumida neste "estado da arte" memorialístico, mas, neles, tento buscar uma alternativa à problemática dentro da tensão entre uma "antropologia da religião" onde "religião" tem um estatuto maior de realidade, e uma "antropologia na religião" quando munidos do instrumental antropológico, consideramos "religião" como um terreno onde convergem outras dimensões, logo uma via propícia para chegarmos a elas (CAMURÇA, 2008).

Ementas e programas da cadeira de "Sociologia da Religião" que elaborei buscaram uma abordagem do fenômeno religioso através dos clássicos Durkheim, Weber e Marx que lançaram as bases da sociologia ao formular a análise da formação da sociedade moderna através do tema da religião. Aqui talvez tenha valido a afirmação de Otto Maduro de que "a sociologia das religiões nasceu junto com a própria sociologia" ou que "a sociologia já nasceu como sociologia das religiões" (1981, p. 41). Isto porque, com o processo de secularização das sociedades ocidentais modernas, a religião pôde então ser vista como objeto da ciência, o que antes era impossível devido ao consenso religioso e ao poder eclesiástico imperantes nessas sociedades pré-modernas. Por outro lado, a religião foi eleita como um dos temas centrais desses clássicos que observaram a transição dessas sociedades em direção à modernidade, pois como ela, religião, tinha se constituído até então, como dimensão fundante da realidade social, foi através de sua crítica que estes autores puderam desvelar os mecanismos encobertos sobre o seu manto - econômicos, sociais, políticos e científicos - que regulavam a sociedade, com isto, formulando suas

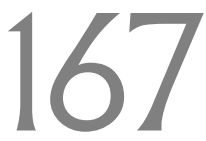


amplas teorias sobre a sociedade moderna $[e$, como partes delas, uma "sociologia da religião").

Dando seguimento aos estudos da sociologia dos clássicos diante da religião, e como derivações destes, os cursos abordavam, em seguida, as teorias sociológicas contemporâneas da religião, como a de Peter Berger, do pluralismo e do "mercado de bens simbólicos", e de Pierre Bourdieu, do "campo religioso".

No decorrer desses cursos de "Sociologia da Religião' e seus correlatos e para dar um sentido mais atual aos enfoques apresentados, resolvi incorporar uma autora, Danièle Hervieu-Léger, que despontava no cenário das Ciências Sociais da Religião contemporâneas pela sua capacidade de atualizar de forma criativa e persuasiva os grandes temas sociológicos - a memória, a tradição, a emoção, a secularização e a (des)institucionalização religiosa -. Inclusive, a partir dos anos 1990, quando visitou o Brasil a convite de Pierre Sanchis, Patrícia Birman e Regina Novaes, proferindo conferências no ISER, vimos incrementar-se a ida de colegas para estágios pós-doutorais e de "bolsa sandwich"- como foi o caso de Cecília Mariz e Emerson Giumbelli - em seu Centre d'études interdisciplinaires des faits religieux em Paris.

Com fins de preparar esses cursos, decidi fazer um investimento na leitura da obra desta autora, que terminou resultando em um texto, o qual obteve relativa repercussão nas ciências sociais da religião do país, devido ao fato, penso, de que até então, muito pouca coisa de Hervieu-Léger estava traduzida no Brasil. Este texto, de nome " $A$ sociologia da religião de Danièle Hervieu-Léger: entre a memória e a emoção", foi publicado como um capítulo do manual "Sociologia da Religião: enfoques teóricos", organizado por Faustino Teixeira e editado pela editora Vozes (2003).

Nele, procurei ressaltar, entre outros aspectos, a ênfase dada pela autora nas transformações operadas pela alta modernidade dentro das grandes religiões, gerando formas desinstitucionalizadas de indivíduos, redes e comunidades emocionais. Para interpretar o fenômeno, Danièle Hervieu-Leger busca uma perspectiva articulada, que procura apreender no interior da própria tensão entre tendências "dessecularizantes" e "secularizantes", ambas presentes nas experiências destas formas emocionais contemporâneas, o caráter intrinsecamente econtraditório do próprio processo de 168 
secularização (1997). Se, por um lado, é acertada a interpretação das comunidades emocionais como um "protesto sócio religioso" contra a razão instrumental e a burocratização da sociedade tecnoindustrial que Ihe conferiu um caráter desmodernizante, por outro lado, a apropriação das narrativas, mitos, rituais das tradições religiosas por esses indivíduos e coletivos emocionais dá-se de forma moderna. pela valorização de subjetividades, pela liberdade individual, pela seleção pragmática daquilo que na tradição religiosa convém às suas necessidades particulares (1990b, 1996, 1997). Para a autora, a ideia de secularização na modernidade ocidental implica menos em perda de influência da religião e mais em um radical processo de mudança operado no seu seio. A maneira como a religião se insere e se dissemina na sociedade contemporânea é marcada pelo crescente abandono de suas formas institucionalizadas dominantes. A isto ela chamou de desregulação institucional.

Parece-me então, que o seu mérito e contribuição para uma sociologia da religião na atualidade seja a perspectiva da articulação de processos aparentemente antinômicos e contraditórios contidos nas novas religiosidades (individuais e comunitárias) e nas mutações que ocorrem no seio das religiões históricas, que se expressam na tensão: fim da religião ou fim da secularização? "retorno do recalcado" ou "culminância emocional da secularização"? (1990c;1997).

\section{c-2 - Reflexões sobre a relação Ciências Sociais e Ciências da Religião}

Além disto, minha experiência nestes últimos anos de frequência e "dupla-pertença" em fóruns de um lado de Ciências Sociais e de outro de Teologia e Ciências da Religião, permitiram-me refletir sobre tensões, competições e contrastes; assim como de colaborações e complementações entre as duas tradições acadêmicas no tratamento da religião no país e fora dele. A resultante destas reflexões também se encontra neste meu livro que no seu título situa as "Ciências Sociais" e as "Ciências da Religião", entre "interlocuções e polêmicas" (2008).

De fato, na história acadêmica recente das Ciências Humanas no país podemos constatar até agora quase que a presença hegemônica das Ciências Sociais nos estudos

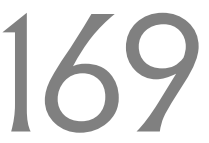


sobre a religião, numa trajetória que se inicia com autores hoje clássicos como Roger Bastide e Cândido Procópio Camargo, firmando uma tradição que tem exercido um profundo impacto na recente constituição da área das Ciências da Religião. Neste particular, há que se registrar o estranhamento e incômodo destas prestigiosas Ciências Sociais face ao recurso das iniciantes Ciências da Religião no Brasil (embora na Europa remontando ao século XIX] de utilizarem suas teorias e métodos para compor um campo de saber próprio. Acrescido a isto, observa-se uma desconfiança por parte das Ciências Sociais frente à eleição do objeto religião como merecedor de uma "ciência" inteiramente dedicada a ele. Isto tem levantado suspeitas, como a do importante sociólogo da religião Flávio Pierucci, de que as Ciências da Religião teriam finalidade mais apologética que científica, encobrindo os "interesses religiosos" de seus agentes. Diz ele: "poderíamos multiplicar indefinidamente a lista de agentes religiosos que se autoproclamam cientistas simplesmente porque fazem "ciência da religião"(1999: 248 n.5; grifo meu).

Diante deste quadro, várias questões são suscitadas, como: quais são as instâncias de validação para o conhecimento produzido pelas Ciências da Religião quando utilizam a teoria das Ciências Sociais? Os fóruns científicos da Sociologia e Antropologia ou os das Ciências da Religião? Qual a vantagem de fazer cursos de Ciências da Religião diante daqueles de Ciências Sociais onde se pode pesquisar o tema da religião? Qual a identidade dos formandos destes cursos, se cientistas sociais ou cientistas da religião? Também neste ponto, as reflexões encaminhadas no livro defendem a articulação e a interconexão das Ciências da Religião com as Ciências Sociais. Ou seja, que as Ciências da Religião que se utilizam das metodologias e teorias das Ciências Sociais busquem estar sintonizadas com as teorias e pesquisas mais renovadoras desenvolvidas neste âmbito; assim como busquem funcionar como um laboratório avançado e especializado de experimentações no tema da religião que possa também fornecer às Ciências Sociais novas perspectivas teóricometodológicas desenvolvidas no campo das Ciências da Religião a partir de epistemologias sociológicas e antropológicas.

\section{c3 - Reflexões sobre o estatuto das Ciências da Religião no campo das Ciências Humanas no país}

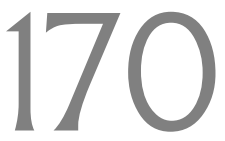


Além da interface das Ciências da Religião com as Ciências Sociais, minha vivência e prática acadêmica dentro da área das Ciências da Religião propriamente dita permitiram-me refletir sobre o estatuto epistemológico desta nova área acadêmica no país, buscando oferecer uma contribuição à referida área, a partir do lugar onde me situo (minha formação enquanto cientista social, circunscrita inicialmente à minha pertença ao Programa de Juiz de Fora). A experiência enquanto consultor e membro do Comitê da Avaliação da CAPES para os PPGs da subárea da área de "Filosofia", chamada "Teologia e Ciências da Religião" no triênio 2004-2006 e no ano de 2007 do triênio 2007-2009 (interrompido para realização de meu pós-doutorado em 2009), forneceu-me um espectro maior de conhecimento da totalidade dos PPGs de nossa recente área acadêmica no cenário das Ciências Humanas no Brasil.

Posso citar como contribuições ao debate sobre os critérios epistemológicos para delimitação de nossa área acadêmica os seguintes ensaios: "Ciência da Religião, Ciências da Religião, Ciências das Religiões? Observações de um antropólogo a partir da experiência no corpo docente de um Programa de Pós-Graduação da Área" (2001); "Entre as Ciências Humanas e a Teologia: gênese e contexto do Programa de Pós-Graduação em Ciência da Religião de Juiz de Fora em cotejo com seus congêneres no Brasil" (2003), depois reunidos a outros artigos e publicados em meu livro dedicado a este tema (2008). Além destes, escrevi também "Les Sciences Religieuses: um olhar a partir do Brasil para o campo de estudos das ciências da Religião na França" (2011), aproveitando meu pós-doutorado na França quando, entre outras coisas, reuni um material sobre as "sciences religieuses" neste país; e, por fim, o capítulo "Religião como organização" no prestigiado "Compêndio de Ciência da Religião", tratado que aborda todos os aspectos desta área acadêmica com dezenas de colaboradores, organizado por Frank Usarski e João Décio Passos (Paulinas/Paulus, 2013), ganhador do Prêmio Jabuti de Literatura naquele ano para esta categoria de publicação.

Este conjunto de ensaios visou resenhar as tensões constitutivas do atual campo das Ciências da Religião no país. Uma primeira, que divide as Ciências da Religião entre os defensores da área como um campo (inter)disciplinar e os que a veem como uma disciplina

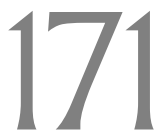


básica. Uma segunda, entre os que veem a religião numa perspectiva essencialista de fenômeno irredutível, e os que a consideram, conforme uma perspectiva reducionista, epifenômeno de outras realidades que a determinam. Em seguida, debato com a Teologia e a Fenomenologia a partir da visão antropológica, defendendo uma hermenêutica compreensiva da religião, ou seja, captá-la "desde dentro", "em seus próprios termos", numa concordância com as duas primeiras, mas se distinguindo delas quando considera que a alteridade da religião, passível de interpretação, não a faz distinta de outras alteridades tão enigmáticas quanto a sua (como a arte, a estética, a sexualidade, o gênero e as ideologias] que também devem ser objeto de mesma postura compreensiva de abordagem. Por fim, apresento como perspectiva, para o perfil acadêmico das Ciências da Religião, que sua meta de excelência deva buscar equivalência com as teorias "de ponta" das Ciências Humanas e Sociais. E que as Ciências da Religião, parte integrante das Ciências Humanas, teriam como diferencial a seu favor o fato de poderem oferecer um foco especial e uma alta concentração de saberes das Ciências Humanas e Sociais quando o tema for religião.

Fiquei muito recompensado deste meu esforço não ter passado despercebido, pois, no balanço sobre a produção antropológica realizado por Ronaldo Almeida no tomo Antropologia do compêndio "Horizontes das Ciências Sociais no Brasil", sob o patrocínio da ANPOCS, este assinala em nota, a partir de minhas reflexões, a "marginalidade" do pressuposto ontológico da religião nas Ciências Sociais no Brasil, mas não nas recentes Ciências da Religião e da minha perspectiva de colocar os dois enfoques em diálogo dentro da "chave da interdisciplinaridade" (ALMEIDA, 2010:368, nota 2).

\section{c4 - Reflexões sobre o "Campo Religioso Brasileiro"}

A experiência na docência da disciplina "Campo Religioso Brasileiro" para o Mestrado/Especialização e da disciplina "Religiões no Brasil" para o Doutorado, ambas no PPCIR, assim como a elaboração da ementa e diversos programas e ainda da redação da Linha de Pesquisa cadastrada no nosso PPG com este mesmo nome, ensejou uma reflexão de minha parte em torno deste tema que resultou numa série de publicações, que,

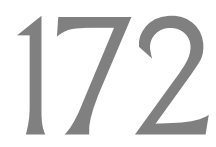


sistematizadas, expressam um perfil recorrente e representativo de um dos meus interesses acadêmicos: o campo religioso brasileiro. Vale dizer que meu primeiro Projeto de Pesquisa, com o qual ingressei na UFJF, cadastrado na Pró-Reitoria de Pesquisa, chamava-se "O Campo Religioso Brasileiro enquanto um espaço de interações simbólicas" (1997-2002), e, atualmente, em meu projeto de bolsa produtividade do CNPQ - sobre o qual discorrerei mais a frente - o Campo Religioso Brasileiro é um dos pilares sobre o qual se desenvolve.

A noção de "Campo Religioso Brasileiro" consolidou-se nas Ciências Sociais voltadas para o estudo do fenômeno religioso no Brasil por volta dos anos 1990, a partir da influência da teoria de Pierre Bourdieu (da produção e consumo de bens religiosos por agentes/consumidores e das relações de concorrência entre instituições produtoras de capital religioso internas a este "campo"). Defendo que no Brasil a noção ganhou uma interpretação um pouco diferenciada e mais alargada em relação à original, ou seja, voltada para estabelecer uma comensurabilidade entre as distintas religiões que compõem este panorama diverso, esparso e disperso no país. Nesse particular, a reflexão do antropólogo Pierre Sanchis foi marcante para a elaboração de uma teoria que fornecesse inteligibilidade à pluralidade religiosa do Brasil, dentro da chave que ele formulou: da pré-modernidade, modernidade e pós-modernidade $(1995,1997,1998)$. Também trilhando, cada um à sua maneira, esta senda aberta por Sanchis, vários autores deixaram sua contribuição a esta temática, como Carlos Rodrigues Brandão (1988), José Jorge de Carvalho (1992, 1994), Antonio Flávio Pierucci $(2004,2006)$, A. F. Pierucci e Reginaldo Prandi (1996), Patrícia Birman (1994), Maria das Dores Campos Machado e Cecília Mariz (1994, 1998), Carlos Steil (2001), Léa Freitas Perez (2011), Wagner Gonçalves da Silva $(2006,2007)$, entre outros. E, dentre estes, também posso situar meu esforço particular de buscar elementos para configurar e delimitar esta pluralidade em um campo - ainda que dentro de sua fluidez e porosidades -, levando em conta as tensões e complementações entre as tendências que o atravessavam, como tradição/modernidade; hegemonia/pluralismo religioso; institucionalização/desinstitucionalização; sincretismos e trânsitos e/ou competições e conflitos.

Esta perspectiva de interpretar a dinâmica e as "linhas de força" que compõem este campo levaram-me a produzir alguns trabalhos de mais visibilidade em meu currículo,

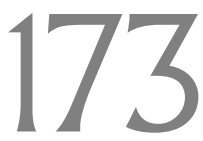


como: "Entre sincretismos e guerras santas: dinâmicas e linhas de força do campo religioso brasileiro" publicado na Revista USP (2009), quando tive a oportunidade de dedicá-lo a Pierre Sanchis pelos seus 80 anos, na época, e, agora, ao mencionar este fato, reafirmo minha gratidão a sua presença inspiradora nos meus trabalhos, cursos e orientações. Também os capítulos "A realidade das religiões no Censo do IBGE-2000" (2006, p. 3548) e "O Brasil religioso que emerge do Censo de 2010: consolidações, tendências e perplexidades" (2013, p. 63-87), ambos publicados em coletâneas organizadas por Faustino Teixeira e Renata Menezes pela editora Vozes (2006, 2013). E, ainda, "O futuro das religiões no Brasil: o enfoque das Ciências da Religião", uma conferência que pronunciei no IV Congresso da Associação Nacional de Pós-Graduação em Teologia e Ciências da Religião (ANPTECRE), depois publicado pela associação (2014). Por fim, meu livro chamado "Espiritismo e Nova Era: Interpelações ao Cristianismo Histórico" (2014), que agrupou textos sobre a relação entre estas três configurações religiosas do campo religioso brasileiro, produto de pesquisas, orientações e cursos realizados em todos estes anos.

Importante ressaltar que algumas de minhas últimas análises sobre o "campo religioso brasileiro" tiveram como suporte os dados do Censo do IBGE 2000 e 2010. E isto indica uma tendência que vem se evidenciando nas Ciências Sociais que tratam do fenômeno religioso no Brasil, aquela de incorporar as pesquisas quantitativas - de forma direta ou utilizando dados já tabulados por outras instituições - mediante a utilização de surveys, questionários aplicados a extratos da população, trabalhados sob método estatístico.

Dentre os trabalhos de referência desta fase que se inaugura nos anos 1990, destaco o livro "A realidade social das religiões no Brasil", de Antônio Flávio Pierucci e Reginaldo Prandi (1996), em que me inspirei para o título do meu primeiro texto sobre o panorama religioso brasileiro no Censo de 2000. O livro de Prandi e Pierucci reunia textos que traçavam um panorama das religiões no país na sua relação com a política/voto, na demarcação da extensão/limites da "liberdade religiosa" diante das "liberdades civis" e ação normativa do Estado visando o bem comum, assim como na estruturação do chamado "mercado concorrencial" que as próprias religiões estabeleciam

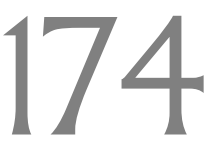


entre si. Para tal, fizeram uso dos dados do survey aplicado na pesquisa do Instituto de Pesquisa DataFolha. Ambos os autores foram formados na escola sociológica de Cândido Procópio Camargo, pioneira nas pesquisas sobre religiões no país, baseada em dados estatísticos do IBGE para as décadas de 1960 e 1970. Outras abordagens quantitativas e demográficas do quadro geral das religiões no Brasil foram realizadas, como o detalhado trabalho coordenado por César Romero Jacob que resultou no "Atlas de filiação religiosa e indicadores sociais no Brasil" (2003).

Também importante registrar que participei de um investimento em pesquisas quantitativas sobre o segmento da juventude (secundarista e universitária) com a religião. Experiência que começou com um pool de pesquisas sobre os universitários dos cursos de Ciências Sociais e sua relação com a dimensão religiosa em diversas universidades do país, coordenada pelo NER/URFGS e, depois, publicada em Debates do NER (2001). Como desdobramento empreendi uma pesquisa sobre a juventude do ensino médio da rede pública de ensino de Minas Gerais junto com as colegas Fátima Tavares e Léa Perez, publicada no livro "Ser jovem em Minas Gerais: religião, cultura e política"(2009).

Mais recentemente, estabeleceu-se em nossa área das Ciências Sociais da Religião um debate sobre as práticas, o alcance e os limites deste método lassim como o recurso aos dados do Censo IBGE) para o estudo do conjunto das religiões no Brasil. Pude participar destas iniciativas com duas reflexões, uma que avaliava o papel das assessorias prestadas pelo ISER ao IBGE (uma das quais, a sobre o Censo de 1991, em que participei na qualidade de consultor da ONG), intitulada " $A$ Religião e o Censo - Enfoques Metodológicos: uma reflexão a partir das consultorias do ISER ao IBGE sobre o dado religioso", publicada em "Comunicações do ISER" (2014); outra em que comentava, junto com outros colegas, um dos últimos textos da antropóloga Clara Mafra, chamado "Números e narrativas", ao qual nomeei "Uma meta-reflexão sobre as pesquisas das Ciências Sociais da Religião a partir dos dados do Censo IBGE', publicados em Debates do NER (2013).

\section{d- A participação na Associação dos Cientistas Sociais da Religião do Mercosul (ACSRM]}

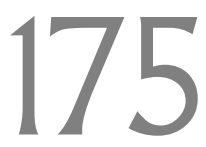


Em 1996, depois de um ano na docência no Mestrado/Especialização em Ciência da Religião na UFJF, participei das VII Jornadas sobre Alternativas Religiosas na América do Sul, realizadas em Porto Alegre. O impacto desta participação foi similar àquele que experimentei em 1989 ao conhecer pessoalmente e de chofre o conjunto de referências bibliográficas sobre "religiões populares" no "Congresso sobre o Padre Cícero e os romeiros", que mencionei acima. Desta feita, o encontro foi com um naipe de primeira grandeza dos pesquisadores das Ciências Sociais que estudavam, naquela época, o tema da religião: Antonio Flávio Pierucci (já falecido), Reginaldo Prandi, Ari Pedro Oro, José Jorge de Carvalho, Rita Segato, além de reencontrar Pierre Sanchis e Otávio Velho e colegas dos anos 1990 do tempo do doutorado e do ISER no Rio que haviam galgado uma posição de destaque no campo acadêmico referido, como Maria das Dores Campos Machado, Cecília Mariz e Carlos Steil. Além desses, os pesquisadores da Argentina, como Fortunato Mallimaci, Abelardo Soneira (já falecido), Alejandro Frigerio, Maria Julia Carozzi e Pablo Semán, o chileno Cristián Parker e os uruguaios Néstor Da Costa e Renzo Pi Hugarte djá falecido).

No decorrer do tempo, com o aumento de minha participação nos eventos dentro de uma maior presença institucional neles (participei da organização das VIII Jornadas, realizadas no Rio de Janeiro em 1997, representando nosso PPG de Ciência da Religião de Juiz de Fora), pude ir gradativamente podendo contribuir de forma mais efetiva na Associação. Penso também que a participação de "delegações" representativas de Juiz de Fora nas Jornadas subsequentes, com alunos (mestrandos e doutorandos) e colegas docentes possa ter influído no fortalecimento de minha inserção mais institucional na ACSRM. Relembro aqui um comentário jocoso do colega Ayrton Jungblut, da PUC-RS, sobre nossa presença "corporativa", numa destas Jornadas: "Aqui existem três maiorias: os brasileiros, os argentinos e o pessoal de Juiz de Fora!".

Na gestão da presidência de Maria das Dores Campos Machado (2003-2005), fui eleito para o Conselho Diretivo junto com Lísias Nogueira Negrão, da USP, representando o Brasil. Na presidência de Maria Julia Carozzi (2005-2007), participei da diretoria da Associação no cargo de Tesoureiro. Na presidência de Carlos Steil (2007-2009), participei de novo da diretoria no cargo de Secretário Geral da Associação. E, agora, na Assembleia

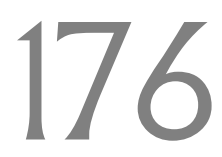


Geral do último congresso das Jornadas em Porto Alegre, fui designado novamente para a diretoria no cargo de Pró-Secretário na gestão da presidência de Emerson Giumbelli para o biênio 2014-2015.

Dentro destas funções na ACSRM, participei de Comissões Julgadoras para premiar melhores trabalhos de jovens associados mestrandos e doutorandos; das diretrizes editoriais para a revista "Ciências Sociais e Religião/CienciasSociales y Religíon" da Associação, da organização de publicações como o livro "Religiones y Culturas: perspectivas latino americanas", em parceria com Carlos Steil e Eloisa Martín (2009).

Mas um dos saldos principais destas atividades foi poder ter conhecido, de forma mais ampla, análises e formulações produzidas na Argentina, Uruguai, Chile e México sobre as realidades religiosas destes países e assim intercambiar conhecimentos. Devido a esta participação, partilhei mesas redondas, organização de GTs com vários colegas latinoamericanos, quando parcerias e vínculos mais duradouros foram estabelecidos, o que redundou em visitas de alguns destes, como Pablo Semán, Eloisa Martín e Juan Esquivel ao nosso PPG em Juiz de Fora.

\section{e -Participação no Programa de Pós-Graduação em Ciências Sociais da UFJF}

No final do ano de 2004, o Departamento de Ciências Sociais da UFJF obteve da CAPES a certificação para a criação de seu Programa de Pós-Graduação que começou seu funcionamento em 2005. No entanto, por sugestão do consultor para este processo, o sociólogo Reginaldo Prandi, e, depois, pela própria Comissão Avaliadora da CAPES, foi necessário que o corpo docente deste PPG iniciante se configurasse numa paridade entre sociólogos, antropólogos e cientistas políticos. Como, naquela época, o Departamento de Ciências Sociais não contava com nenhum antropólogo nos seus quadros, devido a aposentadorias e transferências dos profissionais da área, o professor Rubem Barboza, redator do projeto de Mestrado em Ciências Sociais, entusiasta deste e primeiro coordenador do curso, convidou-me - assim como à colega Fátima Tavares - na qualidade de antropólogos, que integravam o Departamento e o PPG em Ciência da Religião, para a composição do corpo docente desse novo Mestrado.

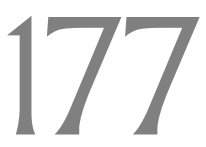


Foi assim que, a partir de 2005, passei a atuar em uma segunda Pós-Graduação na UFJF. Para meus interesses pessoais e acadêmicos, foi importante abrir esta segunda frente de trabalho, pois, nesse ambiente, pude retomar as pesquisas sobre a "antropologia da esquerda" que não se aplicava diretamente ao PPG de Ciência da Religião, e, ao lado disto, agregar outros interesses, como pesquisas sobre juventude, movimento estudantil, turismo, consumo e lazer e, ainda, articular estas dimensões com o tema da religião. Esta perspectiva redundou em cursos oferecidos no Mestrado em Ciências Sociais, como aquele intitulado "Rito, poder e instituições", ministrado em 2005/2 e de novo em 2010/2, orientações de Mestrado e Doutorado cobrindo os temas de juventude, música, política, gênero, assistência social, sistema prisional, todos articulados à dimensão religiosa.

Dando seguimento ao meu interesse no tema da "antropologia da esquerda", a partir de então desenvolvido dentro do PPGCSO da UFJF, concentrei esforços na produção de alguns trabalhos relevantes para meu currículo, como o capítulo chamado "Revolução e imaginário no ideário comunista", publicado no livro Cultura e Instituições Sociais, organizado pelo colega Gilberto Salgado, já falecido (2006), e também a apresentação de trabalhos em fóruns de excelência das Ciências Sociais, como: "Intelectualidade 'periférica' e militância política: adesão dos intelectuais ao Partido Comunista Brasileiro (PCB) 1922-1960", no GT "Intelectuais e política", coordenado por Werneck Vianna e Rubem Barboza na 34 ${ }^{\mathrm{a}}$ Reunião Brasileira da ANPOCS (2010). Além desses, numa perspectiva mais histórica, o capítulo em parceria com o historiador Daniel Aarão Reis, chamado "O Movimento Revolucionário 8 de Outubro (MR-8). Da luta armada contra a ditadura à luta eleitoral no PMDB", publicado em "As Esquerdas no Brasil - Revolução e Democracia, 1964..." organizado por ele e Jorge Ferreira (2007).

Numa perspectiva mais alargada desta "antropologia simbólica da política" para além dos marcos da esquerda e do comunismo, produzi também capítulos em coletâneas como: "Liturgias políticas e simbolismo do poder", no livro "O Sagrado e o Urbano diversidades, manifestações e análises" (2008, p. 45-60) e "A sacralização da política no mundo moderno através dos rituais", no livro organizado pelo historiador Artur Cesar Isaia, "Crenças, Sacralidades e Religiosidades: entre o consentido e o marginal” (2009, p. 241-248).

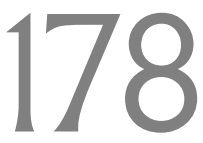


Também é digno de nota o registro de que fui vice-coordenador do PPGCSO no período de 2011-2013, quando tive também a oportunidade de me envolver com questões institucionais e acadêmicas desta área chave de conhecimento das Ciências Humanas, dentro e fora da UFJF. Dentre estas experiências, sublinho a participação no Fórum dos Coordenadores de PPGs em Sociologia junto ao Comitê de Avaliação da CAPES em outubro de 2011, no qual se traçaram, no período, os rumos dos critérios de avaliação da referida área acadêmica. Continuo, até o presente momento, como membro efetivo do PPGCSO, contribuindo com o Programa na docência, pesquisa e orientação. Muito me honra o convívio com estes meus pares das Ciências Sociais que complementa minha outra pertença ao ambiente acadêmico das Ciências da Religião.

\section{f- O Pós-Doutorado na École Pratique des Hautes Études - Sorbonne}

No estágio pós-doutoral que realizei em Paris, durante o período de abril de 2009 a março de 2010 no laboratório "Groupe, Sociétés, Religions, Laícités" (GSRL) da École Pratique des Hautes Études e do CNRS, devido à centralidade que o tema da laicidade goza entre os estudos da religião na França e, particularmente, nesse centro de pesquisa, essa situação interpelou-me para um investimento nesse tema que expressa entre nós, as relações da religião com o Estado e com a esfera pública no Brasil. Embora o objeto de minha pesquisa de pós-doutorado fosse um estudo comparado de estilos do catolicismo no Brasil e na França - o que resultou numa interlocução profícua com especialistas do catolicismo na França membros deste laboratório e apresentações de seus resultados em seminários e palestras tanto na França quanto no Brasil -, as indagações sobre o quadro de laicidade no Brasil dirigidas a mim por estes colegas franceses e certa improvisação nas minhas respostas me fizeram desejar encarar este tema mais sistematicamente no meu regresso ao país.

Envolvendo-me no debate e na leitura dos trabalhos dos colegas que já há algum tempo vêm se dedicando a esta questão, como Emerson Giumbelli, Paula Montero, Ricardo Mariano, Ari Pedro Oro, Joanildo Burity, Maria das Dores Campos Machado, Júlia Miranda e outros; assim como na revisão de uma literatura internacional sobre "laicités" e

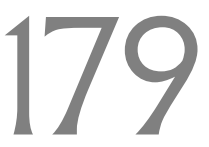


"secularisms", busquei analisar o estatuto deste dispositivo jurídico-estatal que é laicidade ou secularismo dentro da singularidade brasileira. Neste sentido, tornei-me partidário desta nova corrente interpretativa da laicidade/secularismo que irrompe a partir das obras de Jose Casanova (1994) e Talal Asad (1993), para quem o conceito não reproduz simplesmente experiências históricas "clássicas" dos países centrais (mesmo que estas possam se constituir como uma referência) que implicariam numa retração necessária do religioso, mas que no nosso e em muitos outros casos, funcionaria como relações e arranjos distintos entre religião e Estado, todavia, com resultados não definidos de antemão, mas dados no curso dos processos.

Examinando dimensões da presença religiosa na esfera pública no país - educação, assistência social, sistema prisional, etc. - em pesquisas e em orientações de dissertações e teses, arrisco-me a fazer a sugestão de que a experiência histórica e cultural da relação religião e Estado no Brasil podem ser reveladoras de uma considerável improvisação, informalidade na relação entre agentes públicos e lideranças religiosas para lidar com a presença do religioso nesse espaço definido como estatal/público/laico. Ou seja, que uma das características históricas da modelagem da laicidade/secularismo no Brasil se encontra no não equacionamento no seio da sociedade de uma normatização para o estabelecimento deste dispositivo. Isso permitiu e vem permitindo os arranjos mais variáveis toda vez que acontecem interações e fricções entre religiões e esfera pública.

Essas pistas anunciadas nesses meus trabalhos podem ser aprofundadas num programa de estudos (que já se esboça no meu projeto de Bolsa de Produtividade CNPQ sobre o qual me deterei adiante) para responder às seguintes questões: a presença ostensiva do campo religioso no espaço público no Brasil significa possibilidades de um retrocesso em direção a um regime confessional? Seria papel da academia que estuda o fenômeno contribuir para uma normatização para atuação das religiões na esfera pública no Brasil? Ou deve-se respeitar o interesse proativo das religiões na sua atuação no domínio republicano segundo seus valores morais e concepções próprias de laicidade?

Todas estas questões e outras que delas se desdobram foram preocupações de cursos oferecidos na Pós-Graduação em Ciência da Religião como "Religião e espaço público" (2012/1), “Tópicos Especiais em Religião e Espaço Público” (2012/2); assim como

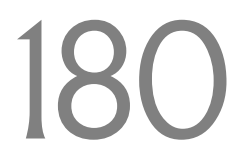


na Graduação em Ciência da Religião, como “Religião, política e espaço público” (2013/2). Também expressas em artigos, como aqueles que escrevi em parceira com minha exorientanda Sueli Martins "Sobre a permanência e a naturalização do catolicismo na esfera pública no Brasil: o caso de uma escola municipal" (2013), "A laicidade e o 'jeitinho brasileiro': formas diversificadas e improvisadas de regulação do religioso em ambientes laicos e públicos: o caso das escolas municipais de Juiz de Fora-MG" (2014), e no capítulo do livro da ACSRM sobre as XVII Jornadas intitulado "Seriam as religiões no Brasil atores legítimos ou espúrios na arena pública e no jogo político?", que está no prelo para sair ano que vem.

Também minhas relações com o "Groupe, Societés, Religions,Laícités" [GSRL), após meu regresso ao Brasil, só tenderam a estreitar-se. No ano de 2011, fui aceito como membro do Laboratório no estrangeiro, em 2010 e 2013, realizei duas visitas técnicas à instituição em Paris. Em outubro de 2012, recebi o professor Philippe Portier, diretor do Laboratório e meu supervisor do pós-doutorado, para duas semanas de cursos e palestras nos PPGs de Ciência da Religião e Ciências Sociais da UFJF. Articulei traduções de muitos dos seus textos em revistas brasileiras de referência no estudo da religião no Brasil, como "Religião e Sociedade", "Estudos de Religião" "Horizonte" "REVER", "Debates do NER" e na Revista "Numen" do nosso Departamento de Ciência da Religião. Também a convite do editor da Revista REVER, da PUC-SP, organizei um dossiê sobre o GSRL, seus pesquisadores e estudos sobre religião na França, intitulado "Panorama religioso na França contemporânea: laicização e pluralidade", que introduziu artigos de pesquisadores do Laboratório como Philippe Portier, Olivier Bobineau e Martine Cohen (2010).

Por fim, ainda como saldo do estágio pós-doutoral no GSRL, dentro do meu projeto de pesquisa comparativo entre catolicismo na França, além da série de palestras proferidas na França e no Brasil, gostaria de registrar a participação numa Mesa Redonda organizada por Emerson Giumbelli na RBA, o capítulo "Perspectivas teóricas comparadas sobre o catolicismo contemporâneo entre França e Brasil", no livro "Missa, culto e Tambor: os espaços das religiões no Brasil, (2012) e o artigo "Estaria o Catolicismo na França do século XXI caminhando em direção a um perfil comunitário?", publicado em "Religião e Sociedade" (2010, p. 74-89). 


\section{g- A obtenção da Bolsa Produtividade CNPQ}

Como foi enunciado ao longo deste texto, minhas preocupações acadêmicas de pesquisa, docência e orientações de dissertações e teses, desde meu ingresso no Departamento e Programa de Ciência da Religião, contemplaram, pela ordem, um interesse na área de "campo religioso brasileiro", seguida de um interesse pelo papel da "religião no espaço público". Estes dois planos corresponderam, então, às duas linhas de pesquisa que compuseram a área de concentração das Ciências Sociais da Religião do Programa (recentemente renomeada de Religião, Sociedade e Cultura). Por ter sido eu quem primeiro redigiu suas ementas, procurei situar estes dois domínios, "campo religioso brasileiro" e "religião e espaço público", enquanto dois planos independentes e correspondentes e inseri-los dentro do cabedal já consolidado de teorias, temáticas, questões e debates de nossa área.

Um plano mais interno, enfocando a interpretação dos ritos, crenças e práticas religiosas, cosmologias e as relações de porosidades e competições que as religiões travam entre si; e um plano mais externo, que contemplasse a análise das relações das instituições religiosas com o Estado, com as esferas públicas da gestão da vida social e o papel destas enquanto um ator relevante na formulação de políticas públicas. A questão era, então, escolher entre estas duas a perspectiva mais adequada para cada pesquisa, artigo, dissertação ou tese a ser desenvolvida.

Em fins de 2013, propus o seguinte Projeto de Pesquisa para concorrer a uma bolsa de Produtividade CNPQ, que foi aceito para ser desenvolvido no período de 2014-2017. 0 projeto, que se intitula "Entre o campo religioso e o espaço público: fronteiras conceituais e empíricas das religiões no Brasil contemporâneo", almeja articular estes dois planos de modo a retirar desta perspectiva relacional todas as implicações possíveis entre eles. A pretensão deste projeto é a de contribuir para superar uma distorção apontada por Paula Montero na prática acadêmica das Ciências Sociais da Religião no país, qual seja "esse vazio que separa uma antropologia das microrrelações e uma sociologia dos atores políticos" 
(MONTEIRO, 1999, p. 338), ambas assentadas "em recortes disciplinares bem demarcados, com poucas zonas de interconexão e diálogo" (MONTEIRO, 1999, p. 331).

O objetivo da pesquisa é de chegar às mediações e relações entre os dois planos do "campo religioso" e do "religioso no espaço público" através de uma contextualização dos espaços públicos ocupados pelas religiões, suas estratégias, seus antagonistas e embates, e conjugá-la com a dimensão da construção do significado. Enfim, enfocar de forma relacional os níveis institucional e experiencial nas suas particularidades e na sua interdependência.

Ao cabo disto, buscar chegar às formulações que articulem o simbólico, a experiência e performance de cada religião e das competições e trocas que se dão entre elas em torno destas dimensões (a parte interior do fenômeno religioso) com os interesses, as disputas e as estratégias dos grupos religiosos dentro do cenário das instituições laicas e republicanas com que eles interagem ( a parte exterior do fenômeno religioso).

Julgo que, a partir da realização deste Projeto, descortina-se um horizonte mais amplo para o que já estava realizando em termos de docência, orientação e pesquisa nos espaços acadêmicos onde atuo. Continuo a caminhar...

\section{Conclusão}

Ao cabo destes vinte anos de docência e pesquisa no Departamento de Ciência da Religião, no seu Programa de Pós-Graduação, na sua Especialização e no seu recente curso de Graduação - assim como minha atuação no Programa de Pós-Graduação em Ciências Sociais - quando pleiteio este posto de Professor Titular, gostaria de afirmar que não me sinto chegando aos píncaros da carreira universitária com um saber consolidado sobre o meu metier. Ao contrário, a disposição que mais me move e estimula hoje é a de aprender. Assim como a consciência de uma grande quantidade de saberes teóricos e temáticos que ainda me falta cobrir. Observando os jovens colegas que entram na nossa universidade, depois de concursos ultra seletivos e exigentes, onde têm que provar um

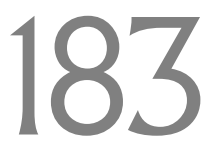


domínio sobre um campo muito extenso de conhecimentos - tanto na sociologia, quanto na antropologia ou nas ciências da religião, disciplinas que acompanho mais de perto em seus desenvolvimentos acadêmico e institucional -, desperta-me a vontade e a responsabilidade de tentar acompanhar a rápida renovação epistemológica por que passam esses domínios do saber das Ciências Humanas.

Realização, se é que se pode dizer que algum dia alcança-se este patamar, é o que tenho experimentado na vida pessoal. Mesmo assim, sempre desafiado pela dinâmica da vida e suas transformações que exigem um constante envolvimento nas relações com minha companheira e meus filhos. No entanto, dá-me muito contentamento ter minha mulher Beth, antropóloga, docente desta universidade trabalhando e partilhando muito proximamente suas inquietudes profissionais, éticas e afetivas. Dos filhos, a mais velha Mariana, agora casada e desenvolvendo atividades profissionais no ramo da pequena empresa, experiência profissional consideravelmente distante de minhas capacitações e domínios; o Rodrigo, graduado em Turismo e mestrando do nosso curso de Ciências Sociais, bem mais perto, mas com seu estilo e "voo próprio" e, por fim, a Nina, caçula, que nos seus 14 anos desabrocha para o mundo das artes.

Tenho que agradecer a esta universidade e a Juiz de Fora, (sem esquecer o Rio de Janeiro e Fortaleza), Iugar que me proporcionou o reconhecimento, as amizades e o sustento neste meu período de maturidade.

Quanto à religião e ao socialismo, estas realidades, outrora tão sólidas, vêm sofrendo, neste século XXI, intensos revolvimentos que as desfiguram e as reconfiguram em outras formas, atravessadas por uma pluralidade de fatores numa autêntica "mistura de gêneros" de que nos falava Clifford Geertz. As configurações em torno da primeira inundam como uma torrente o presente da realidade mundial nas suas múltiplas maneiras; ao passo que o segundo voltou a ser aquela utopia do século XIX, proclamada nas revoltas iracundas dos descontentes e perseguidos destes tempos.

E nós, docentes e pesquisadores, na incessante busca de interpretar nestes fluxos o seu sentido fugidio!

\section{4}




\section{REFERÊNCIAS BIBLIOGRÁFICAS}

ASAD, Talal. Formation of the secular: Christianity, Islam, Modernity. Stanford: Stanford University Press, 1993.

AZZI, Riolando. "Catolicismo Popular e Autoridade Eclesiástica na Evolução Histórica do Brasil." In: Religião e Sociedade nº 1, Rio de Janeiro, ISER, 1977, pp. 125-149.

ALMEIDA, Ronaldo. "Religião em Transição". In: Horizontes das Ciências Sociais no Brasil - Antropologia. Carlos B. Martins e Luiz Fernando Dias Duarte (Orgs.) São Paulo: ANPOCS, 2010, pp.367-405

AARÃO REIS FILHO, Daniel. A Revolução faltou ao encontro. os comunistas no Brasil, São Paulo: Brasiliense, 1989

BARROS, Luitgarde Oliveira Cavalcanti. A Terra da Mãe de Deus. Um estudo do movimento religioso do Juazeiro do Norte. Rio de Janeiro: Francisco Alves, 1988.

BEOZZO, José Oscar. "Irmandades, santuários e capelinhas à beira de estrada". Revista Eclesiástica Brasileira (REB), vol 37/148, 1977, pp.741-758.

BIRMAN, Patrícia. "Cultos de possessão e pentecostalismo no Brasil: passagens." Religião e Sociedade, 17/1-2, 1996, pp. 90-109.

BRANDÃO, Carlos Rodrigues. Os Deuses do Povo. São Paulo, Brasiliense, 1980.

. Ser católico: dimensões brasileiras, um estudo sobre a atribuição através da religião.

In: Brasil \& EUA-Religião e Identidade Nacional. Rio de Janeiro: Graal, 1988, pp. 27-58.

CAMURÇA, Marcelo Ayres. A Comunidade do Joaseiro na guerra dos Coronéis.

Dissertação de Mestrado, PPG em Ciências Sociais, Universidade Federal do Ceará, 1987.

. Marretas, Molambudos e Rabelistas. a revolta de 1914 no Juazeiro, São Paulo:

Maltese, 1994.

A concepção da História na Cultura Comunista. Série Estudos. Rio de Janeiro,

IUPERJ, 1992. 
. "Se essa rua fosse minha'... registro de uma experiência em curso". Rio de Janeiro: Núcleo de Pesquisa do ISER, 1992.

. Conselho Estadual de Defesa da Criança e do Adolescente: Estado e ONGS, uma parceria possível? Rio de Janeiro, FASE/IBASE/IDAC/ ISER e Fundação Fé e Alegria do Brasil, 1994.

. Os melhores filhos do povo. Um estudo do ritual e do simbólico numa organização comunista: o caso do MR8. Tese de Doutoramento. Programa de Pós Graduação em Antropologia Social /Museu Nacional/ UFRJ, 1994.

. "Ética sacrificial e martirológio entre cristãos e comunistas". In: Exemplaridade ética e santidade. Maria Clara Bingemer e Roberto Bartholo [Orgs.). São Paulo: Loyola, 1997, pp. 91117.

."Imaginário, Símbolos e Rituais nos Movimentos e Organizações Comunistas: por uma Antropologia Interpretativa da Esquerda". Religião e Sociedade, vol 19/1, 1998.

. Na 'linha de frente' da questão da infância e juventude: uma análise da atuação dos Conselhos Tutelares no município do Rio de Janeiro (1996-1998), Comunicações do ISER, $\mathrm{n}^{\circ} 51,1999$.

. “Ciência da Religião, Ciências da Religião, Ciências das Religiões? Observações de um antropólogo a partir da experiência no corpo docente de um Programa de PósGraduação da Área". In: Faustino Teixeira (org.) A(s) Ciência(s) da Religião no Brasil: afirmação de uma área acadêmica. São Paulo, Paulinas, 2001, pp.197-232.

. "Religião moderna e esclarecida entre os universitários de Juiz de Fora - MG". Debates do NER, $\mathrm{n}^{\circ}$ 2, 2001, pp.37-64.

- "Entre as Ciências Humanas e a Teologia: gênese e contexto do Programa de PósGraduação em Ciência da Religião de Juiz de Fora em cotejo com seus congêneres no Brasil". In: Silas Guerriero (Org.). O Estudo das Religiões: desafios contemporâneos. São Paulo, Paulinas, 2003, pp. 139-155.

. "A sociologia da religião de Danièle Hervieu-Léger: entre a memória e a emoção". In: Faustino Teixeira (Org.) Sociologia da Religião: enfoques teóricos. Petropólis, Vozes, 2003, pp.249-270.

. "Revolução e imaginário no ideário comunista" publicado. In: Gilberto Salgado(Org.) Cultura e Instituições Sociais. Juiz de Fora, UFJF, 2006, pp.173-205.

\section{6}


. “Comunismo e Religião nas 'voltas do parafuso': o papel da narrativa e do simbólico na transfiguração do cotidiano e na criação de sentido de comunidade". Numen, vol. 09, 2006, pp.68-80.

. "A realidade das religiões no Censo do IBGE-2000". In Faustino Teixeira e Renata Menezes [Orgs.] As Religiões no Brasil: continuidades e rupturas. Petrópolis, Vozes, 2006, pp.35-48.

- “Um balanço do Núcleo de Estudos do PPG em Ciência da Religião da UFJF: a religião entre as Ciências Sociais e Ciências da Religião", Debates do NER, n¹1, 2007, pp.101-118.

__ "An examination of the Center for study on religion, culture and society in the postgraduate program of science of religion at Federal University of Juiz de Fora: the relationship between Social Sciences and Sciences of Religion". Debates do NER, $\mathrm{n}^{\circ} 11$, 2007, pp 95-109.

. "Liturgias políticas e simbolismo do poder". In: O Sagrado e o Urbano: diversidades, manifestações e análises, Paulo A. Nogueira Baptista \& Mauro Passos \& Wellington Teodoro Silva (Orgs.). São Paulo: Paulinas, 2008, pp. 45-60.

. Ciências Sociais e Ciências da Religião: polêmicas e interlocuções. São Paulo, Paulinas, 2008.

. "Entre sincretismos e guerras santas: dinâmicas e linhas de força do campo religioso brasileiro". Revista USP, n 81, 2009, pp. 173-185.

. "A sacralização da política no mundo moderno através dos rituais". In: Crenças, sacralidades e religiosidades: entre o consentido e o marginal. Artur Cesar Isaia [Org.] Florianópolis: Insular, 2009, pp. 241-48.

- Tradicionalismo e meios de comunicação de massa: o catolicismo midiático In: Brenda Carranza; Marcelo Camurça; Cecília Mariz (Orgs.). Novas Comunidades Católicas: busca de espaços na pós-modernidade. São Paulo: Editora Santuário, 2009, pp.59-77.

. Estaria o Catolicismo na França do século XXI caminhando em direção a um perfil comunitário? Religião \& Sociedade, v. 30,2010, pp. 74-89.

. "Panorama religioso na França contemporânea: laicização e pluralidade". REVER, setembro, 2010. 
"Les Sciences Religieuses: um olhar a partir do Brasil para o campo de estudos das ciências da Religião na França". Estudos de Religião, 2011, pp. 12-28.

. "Werneck Vianna e suas inquietações: imagens e ethos da militância comunista". In: Rubem Barboza Filho e Fernando Perlatto [Orgs.). Uma sociologia indignada: diálogos com Luiz Werneck Vianna. Juiz de Fora, Ed. UFJF, 2012, pp.409-422.

"Perspectivas teóricas comparadas sobre o catolicismo contemporâneo entre França e Brasil". In: Gamaliel Carreiro da Silva, Sérgio Figueiredo Ferreti, Lyndon de Araújo Santos, (Orgs.). Missa, culto e Tambor: os espaços das religiões no Brasil. São Luís, EDUFMA/FAPEMA, 2012, pp. 13-28.

. "O Brasil religioso que emerge do Censo de 2010: consolidações, tendências e perplexidades". In: Faustino Teixeira \& Renata Menezes (Orgs.). Religiões em Movimento: o Censo de 2010, Petrópolis: Vozes, 2013, pp.63-87.

. "Religião como organização". In: João Décio Passos e Frank Usarski [Orgs.]. “Compêndio de Ciência da Religião"São Paulo, Paulinas/ Paulus, 2013, pp. 287-299.

"Uma meta-reflexão sobre as pesquisas das Ciências Sociais da Religião a partir dos dados do Censo IBGE - Comentário". Debates do NER, n² 24, 2013, pp.85-92.

. "O futuro das religiões no Brasil: o enfoque das Ciências da Religião". In: Gilbraz Aragão, Newton Cabral, Edênio Valle (Orgs.). Para onde vão os estudos de religião no Brasil? São Paulo, ANPTECRE, 2014, pp. 287-305

."A Religião e o Censo -Enfoques Metodológicos: uma reflexão a partir das consultorias do ISER ao IBGE sobre o dado religioso", Comunicações do ISER, $\mathrm{n}^{\circ} 2014$, pp.08-17.

Espiritismo e Nova Era: Interpelações ao Cristianismo Histórico. Aparecida, São Paulo, Editora Santuário, 2014.

CAMURÇA, Marcelo, AARÃO REIS, Daniel. "O Movimento Revolucionário 8 de Outubro (MR-8). Da luta armada contra a ditadura à luta eleitoral no PMDB". In: Daniel Aarão Reis e Jorge Ferreira (Orgs.). As Esquerdas no Brasil - Revolução e Democracia, 1964... Rio de Janeiro, Editora Civilização Brasileira, 2007, pp. 131-148.

CAMURÇA, Marcelo, PEREZ, Léa Freitas, TAVARES, Fátima. Ser jovem em Minas Gerais: religião, cultura e política. Belo Horizonte, Argvmentvm, 2009.

CAMURÇA, Marcelo, MARTİN, Eloísa, STEIL, Carlos Alberto. Religiones y Culturas: perspectivas latinoamericanas. Buenos Aires, Editorial Biblos, 2009.

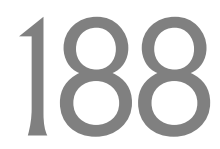


CAMURÇA, Marcelo Ayres, MARTINS, Sueli. "Sobre a permanência e a naturalização do catolicismo na esfera pública no Brasil: o caso de uma escola municipal". Cultura y Religión, vol.17, n 2, 2013, pp. 102-116.

. "A laicidade e o 'jeitinho brasileiro': formas diversificadas e improvisadas de regulação do religioso em ambientes laicos e públicos: o caso das escolas municipais de Juiz de Fora - MG", Numen, vol 17 n 1, 2014. .

CARVALHO, José Jorge. "Características do Fenômeno Religioso na Sociedade Contemporânea". In: O Impacto da Modernidade sobre a Religião. Maria Clara L. Bingemer (Org.), São Paulo: Loyola, 1992, pp.133-160.

. "O Encontro de Velhas e Novas Religiões: esboço de uma teoria de estilos de espiritualidade". In: Misticismo e Novas Religiões. Alberto Moreira \& Renée Zicman (Orgs.), Petrópolis: Vozes, 1994, pp. 64-98.

CASANOVA, José. Public religions in the modern world. Chicago: University of Chicago Press, 1994.

DELLA CAVA, Ralph. O Milagre em Joaseiro. Rio de Janeiro: Paz e Terra, 1977.

DURKHEIM, Émile. As formas elementares da vida religiosa. São Paulo: Paulinas, 1989.

FAUSTO, Boris. A Revolução de 1930: historiografia e história. São Paulo, Brasiliense, 1972.

FERNANDES, Rubem César. "Cultura brasileira: como falar de seu futuro?".

Comunicações do ISER, $\mathrm{n}^{\circ} 33,1989$.

. "Votos para a nova década". Comunicações do ISER, n 40, 1991, pp.03-11.

.Privado, porém Público. O terceiro Setor na América Latina. Rio de Janeiro: Relume Dumará, 1994.

HERVIEU-LÉGER, Danièle. De l'émotion en religion. Renouveaux et traditions. [éd. avec Françoise Champion). Paris, Centurion, 1990b.

."Renouveaux émotionnels contemporains. Fin de la sécularisation ou fin de la religion?".In: Champion, F. \& Hervieu-Léger, D. (éds.). De l'émotion en religion. Renouveaux et traditions. Paris, Centurion, 1990c, pp.217-248. 
" La religion des européens: modernité, religion secularization". In Davie, G. \& Hervieu-Léger, D. (éds.). Les identités religieuses en Europe. Paris, La Découverte, 1996. pp. 09-23.

. "Representam os surtos emocionais contemporâneos o fim da secularização ou o fim da religião". Religião e Sociedade, 18/1, (tradução de Pierre Sanchis), 1997, pp.31-47.

HOORNAERT, Eduardo. "O catolicismo popular numa perspectiva de libertação". Revista Eclesiástica Brasileira (REB), vol. 36, fasc.141, 1976.

JACOB, César Romero et alli. Atlas da filiação religiosa e indicadores sociais no Brasil. Rio de Janeiro: Ed. PUC-RJ; São Paulo: Loyola, 2003.

MACHADO, Maria das Dores Campos \& MARIZ Cecília. Sincretismo e trânsito religioso: comparando carismáticos e pentecostais. Comunicações do ISER, $\mathrm{n}^{\circ} 45,1994$, pp.24-34.

. "Changement recents dans le champ religieux bresilien".Social Compass - revue internationale de Sociologie de la religionvol, 45, n.3, 1998.pp. 350-378,

MADURO, Otto. "Que é sociologia das religiões?". In: Religião e Luta de Classes, Petrópolis: Vozes, 1981, pp.32-46.

MONTERO, Paula. "Religiões e dilema da Sociedade brasileira" in O que ler na Ciência Social brasileira (1970-1995). Vol 1 Antropologia. Brasília, Ed. Sumaré / ANPOCS / CAPES, 1999, pp. 327-367.

OLIVEIRA, Francisco de. Elegia para uma Re(li)gião: Sudene, Nordeste, planejamento e conflito de classe. Rio de Janeiro, Paz e Terra, 1977.

OLIVEIRA, Pedro Ribeiro. Religião e Dominação de Classe. Petrópolis, Vozes, 1985.

OLIVEIRA, Lucia Lippi \& PANDOLFI, Dulce. Fora de Ordem: viagens de Rubem César. Rio de Janeiro: Editora FGV, 2014.

PEREZ, Léa. "Breves notas sobre a religiosidade brasileira". In: Festa, religião e cidade. corpo e alma do Brasil, Porto Alegre: Medianiz, 2011, pp. 121-183.

PIERUCCl, Antônio Flávio. "Sociologia da Religião - Área Impuramente Acadêmica". In: O que ler na ciência social brasileira (1970-1995) Vol 2, Sociologia / Sérgio Miceli (Org.), São Paulo: Editora Sumaré: ANPOCS; Brasília, DF: CAPES, 1999. pp. 237-286.

. "'Bye bye, Brasil', o declínio das religiões tradicionais no Censo 2000". Estudos Avançados, vol 18, 2004, pp.17-28.

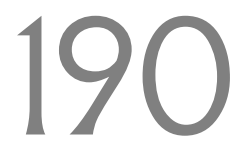


. "Ciências sociais e religião - a religião como ruptura". In: Faustino Teixeira \& Renata Menezes [Orgs.] As Religiões no Brasil: continuidades e rupturas, Petrópolis: Vozes, 2006, pp.17-34.

PIERUCCl, Antônio Flávio e PRANDI, Reginaldo. A realidade social das religiões no Brasil. São Paulo, Hucitec, 1996.

PINHEIRO, Paulo Sérgio. "Classes médias urbanas, formação natureza, intervenção na vida política". In: Boris Fausto (org.). História Geral da Civilização Brasileira, vol. III, O Brasil republicano - Sociedade e Instituições. São Paulo, Difel, 1977.

PORTELLI, Hugues. Gramsci et la question religieuse. Paris: Éditions Anthropos, 1974.

POULANTZAS, Nicos. O Estado, o poder, o socialismo. Rio de Janeiro, Ed. Graal, 1980.

SANCHIS, Pierre. "A Caminhada Ritual”. Religião e Sociedade n 9, 1983, pp.15-26.

. "O campo religioso será ainda hoje o campo das religiões". In: Eduardo Hoornaert (org.). História da Igreja na América Latina e do Caribe: o debate metodológico, Petrópolis: Vozes, 1995, pp. 81-131.

. "O Campo Religioso Contemporâneo no Brasil". In: Ari Pedro Oro, Carlos Alberto Steil (Org). Globalização e Religião. Petrópolis, Vozes, 1997, pp.103-117.

"As Religiões dos Brasileiros". Horizontes, vol 1 n² 2, 1998.

SILVA, Vagner Gonçalves. "Continuidades e rupturas entre neopentecostalismo e religiões afro-brasileiras". In: Faustino Teixeira \& Renata Menezes (Orgs.) As Religiões no Brasil: continuidades e rupturas, Petrópolis: Vozes, 2006, pp.207-228.

"Entre a Gira de Fé e Jesus de Nazaré: Relações Socioestruturais entre Neopentecostalismo e Religões Afro-brasileiras". In: Intolerância Religiosa. impactos do neopentecostalismo no campo religioso afro-brasileiro. São Paulo: Edusp, 2007, pp. 191260.

STEIL, Carlos Alberto. "Pluralismo, modernidade e tradição: transformações do campo religioso”. Ciências Sociales y Religión/Ciências Sociais e Religião, n.3, 2001, pp.115-129.

VELHO, Otávio. "Antropologia e a questão da representação". In Gilberto Velho; Otávio Velho. Duas Conferências. Rio de Janeiro, Editora UFRJ, 1992. 
. "Relativizando o Relativismo"; "Religiosidade e Antropologia" "Religião e modernidade: roteiro para uma discussão. In: Besta-Fera: recriação do mundo. Rio de Janeiro, Relume-Dumará, 1995.

\section{2}

